\title{
AGENDA PENGEMBANGAN STUDI ISLAM DAN IMPLIKASINYA DALAM KAJIAN TAFSIR HADIS DI PERGURUAN TINGGI AGAMA ISLAM
}

\author{
Dzikri Nirwana \\ Fakultas Ushuluddin IAIN Antasari, Jln. Jend. A. Yani, Km. 4.5, \\ Banjarmasin, Kalimantan Selatan, Telp. (0511) 3266593, Hp. \\ 081348169148, e-mail: www.dzikri_nirwana@yahoo.com
}

\begin{abstract}
Abstrak: Pengembangan studi Islam untuk masa sekarang memang masih menyisakan sejumlah persoalan yang sebenarnya berpangkal dari tiga hal, metodologi, materi, dan strategi pembelajaran. Terlebih ketika studi Islam tersebut berada dalam wilayah kajian tafsir dan hadis, maka permasalahan pun menjadi semakin kompleks. Maka sebagai institusi pendidikan tinggi Islam, IAIN dan STAIN sudah saatnya membenahi diri dan membekali para peserta didiknya dengan penguasaan dan pengembangan metodologi yang tepat guna. Hal ini dimulai dengan upaya-upaya dialogis TimurBarat (hiwâr al-masyriq wa al-maghrib), dalam pengertian perlunya sintesis antara pendekatan normatif konvensional seperti tafsir dan hadis yang akar kesejarahannya berasal dari Islam dan pendekatan-pendekatan ilmiah yang muncul di Barat, seperti sosiologi dan antropologi. Dengan pendekatan ganda tersebut, beberapa cacat metodologis dari masingmasing pendekatan, baik normatif maupun historisnya akan dapat dieleminir sekecil mungkin. Kemunculan para pemikir Islam kontemporer, baik dalam skala lokal maupun internasional, dengan gagasan-gagasan baru pengembangan studi Islam terutama kajian tafsir dan hadis, di satu sisi patut untuk diapresiasi sebagai dinamika yang akan memperkaya khazanah intelektual Islam meskipun di sisi lain gagasangagasan mereka juga perlu untuk dikritisi demi pengembangan kajian keislaman yang lebih komprehensif dan integral.
\end{abstract}

Kata-Kata Kunci: Studi Islam, stagnasi metodologis, dialog metodologis.

\section{PENDAHULUAN}

Perguruan Tinggi Agama Islam (PTAI), dengan proses dan sejarahnya, secara kelembagaan telah berdiri sekian puluh yang lalu, baik dalam bentuk Institut
Agama Islam Negeri (IAIN), Sekolah Tinggi Agama Islam Negeri (STAIN) bahkan kini telah berkembang menjadi Universitas Islam Negeri (UIN) dengan beragam fakultas dan jurusannya. Demikian juga 
Program Pascasarjana (PPS)nya yang secara langsung dikelola di bawahnya juga telah dibuka sejak awal tahun 1980-an, dengan Program Studi (Prodi) Studi Islam (Dirasah Islamiyah/Islamic Studies), yang dimulai di IAIN Jakarta dan IAIN Yogyakarta. Kemudian berkembang hampir di semua IAIN dan STAIN.

Sebagai perguruan tinggi yang berbasis Islam, baik di UIN, IAIN, maupun STAIN, Studi Islam menjadi salah satu kajian yang mutlak ada di perguruan tinggi tersebut. Studi Islam tersebut sebenarnya memang sudah ada semenjak Islam itu sendiri datang ke muka bumi. Sudah tentu pada awalnya ketika memahami Islam tersebut dilakukan dengan cara dan pendekatan yang sangat sederhana. Namun seiring dengan perkembangan jumlah dan tingkat intelektualitas masyarakat, maka studi Islam pun turut mengalami perkembangan. Di PTAI yang bercirikan Tri Dharma Perguruan Tinggi (pendidikan, penelitian dan pengabdian masyarakat), studi Islam tentunya harus dilakukan secara kritis dan komprehensif. Untuk itu, diperlukan penguasaan metodologi terhadap kajiankajian keislaman tersebut bagi para civitas akademikanya. Maka tidaklah mengherankan jika Islamic Studies di PTAI menjadi kajian yang wajib bagi setiap mahasiswa, apapun fakultas dan jurusannya. Bahkan pembelajaran studi Islam ini secara berkesinambungan dilakukan tidak hanya pada tingkat sarjana (S1), juga pada tingkat pascasarjana, baik program magister (S2) maupun program doktor (S3). Dengan demikian, para calon intelektual muslim diharapkan akan memiliki bekal dan perangkat metodologis dalam melakukan pengkajian terhadap Islam, sehingga dapat memberikan sumbangan keilmuan (contribution of knowledge) yang orisinil dalam pengembangan ilmu-ilmu keislaman.

Namun dalam prakteknya, studi Islam pada perguruan-perguruan tinggi Islam secara umum belum sepenuhnya memberikan hasil yang siginifikan. Hampir semua mahasiswa belum begitu 
memahami apalagi mengaplikasikan perangkatperangkat metodologis yang dipelajari dalam mengkaji persoalan-persoalan keislaman yang berkembang di masyarakat. Hal ini dapat terlihat ketika mereka mengambil mata kuliah Metodologi Penelitian. Dalam membuat proposal penelitian misalnya, yang menjadi problem krusial selalu pada aspek metodologinya. Para mahasiswa sendiri nampaknya kebingungan ketika ditanya tentang bagaimana metode dan pendekatan yang dipakai dalam penelitian mereka. Padahal ketika sudah mempelajari studi Islam, secara teoritis mereka sudah dianggap menguasai perangkat-perangkat

metodologis, setidaknya pada konsep dasarnya. Sehingga ketika memasuki Metodologi Penelitian, mereka akan mampu mematangkan metodologinya dalam tataran praktis.

Namun yang terjadi justru sebaliknya, kebimbangan metodologis yang tidak jelas ujung pangkalnya. Terlebih ketika studi Islam tersebut diarahkan pada dua disiplin ilmu keislaman yang sangat krusial, yaitu studi al-Qur'an (tafsir) dan studi hadis (kritik dan pemahaman). Pengkajian Islam sebenarnya bertolak dari dua disiplin ini. Oleh karena itu, Jurusan Tafsir Hadis (TH) yang bernaung di bawah Fakultas Ushuluddin di tingkat S1 maupun Prodi TH di tingkat S2 dan S3, mengemban tugas yang maha berat karena mengkaji dua persoalan yang fundamental dalam Islam. Di sinilah problem menjadi semakin kompleks ketika penguasaan metodologi kurang begitu mapan, menyebabkan kajian $\mathrm{TH}$ mengalami stagnasi metodologis karena dasar-dasar epistimologi yang kurang jelas dan penjelalan materi yang berlebihan tanpa diimbangi dengan porsi metodologinya.

\section{PEMBAHASAN}

\section{Beberapa Kendala}

\section{Pengembangan Studi Islam}

\section{Aspek Metodologis}

Secara metodologis, problematika yang dihadapi dalam studi Islam di PTAI cukup memprihatinkan dan berdampak signifikan pada kajian TH. Memang dalam 
pengembangan kajian Islam, terutama dengan menerapkan pendekatan-pendekatan

kesejarahan seperti sosiologi, antropologi, sejarah, dan lainlain maupun pendekatanpendekatan lainnya semisal filsafat, linguistik, hermeneutika, dan lain sebagainya dalam konteks kajian Islam interdisipliner dan multidisipliner mengalami beberapa kendala.

Pertama, dominasi pendekatan normatif terhadap kajian-kajian Islam doktrinal. Faktor penting dominasi tersebut adalah karena pengkajian Islam dengan pembidangan ilmu-ilmu keislaman seperti tafsir dan hadits secara normatif dan individualistik dianggap lebih intrinsik dan menyentuh kesadaran "religiusitas" (sempit) itu. Dengan ungkapan lain, selama ini ada kecenderungan kuat bahwa seorang pengkaji muslim lebih memposisikan sebagai orang yang terlibat (involved), mu'min, believer, insider, dibanding sebagai orang yang mampu mengadakan jarak atau distansi dengan apa yang diyakini dan diamalkan (research). Di PTAI, seperti
UIN, IAIN, dan STAIN, baik keterlibatan maupun pembuatan jarak sama-sama penting. Hanya saja, pembuatan jarak untuk melahirkan sikap kritis adalah problem yang hingga kini masih berkecamuk.

Pada umumnya, para peneliti muslim dalam meneliti agamanya lebih banyak bertolak dari motivasi keagamaan. Dengan kata lain, pengkajian Islam lebih bertujuan untuk melanggengkan kemapanan keyakinan dan aliran yang dianut tanpa dibarengi dengan kesadaran kritis. Padahal Islam, -dengan meminjam pemilahan Wilfred Cantwell Smith yang dikutip muridnya Charles J. Adams- tidak hanya berupa faith (keyakinan), namun juga tradition (tradisi). Tradisi merupakan dimensi keberagamaan yang bersifat eksternal, sosial dan historikal, sedangkan keyakinan adalah dimensi yang bersifat internal, inflabel, transendental-oriented, dan privat. Kedua dimensi ini saling ketergantungan antara satu dengan lainnya. ${ }^{1}$ Dengan

\footnotetext{
${ }^{1}$ Charles J. Adams, "Islamic Religious Tradition" dalam Leonard Binder (ed.), The Study of The Middle
} 
bertolak pada distingsi Smith ini, Adams ingin menegaskan bahwa meskipun tujuan utama (ultimate goal) dari pengkaji agama adalah untuk menemukan rahasia terdalam kehidupan manusia (secrets of inner life), fokus kajiannya harus diarahkan pada aspek historisnya (historical tradition), mengingat hal tersebut berlaku umum dan dapat diterapkan dalam metode penelitian historis. $^{2}$ Dengan demikian, Islam sebagai teks dan

East; Research and Scholarship in the Humanities and The Social Sciences, (New York: John Wiley \& Sons, 1976), hlm. 32. Bandingkan dengan Jalaluddin Rahmat yang memilah agama sebagai ajaran dan keberagamaan. Ajaran merupakan teks, baik lisan maupun tulisan yang sakral dan menjadi rujukan bagi pemeluk agama, sementara keberagamaan (religiosity) adalah perilaku yang bersumber langsung atau tidak langsung kepada nash. Lihat Jalaluddin Rakhmat, "Metodologi Penelitian Agama" dalam Taufik Abdullah (ed.), Metodologi Penelitian Agama; Sebuah Pengantar, (Yogyakarta: Tiara Wacana, 1990), hlm. 91. Lihat juga Musahadi, "Islam sebagai Sasaran Studi" dalam Kamaruddin Amin et.al. (eds.), Quo Vadis Islamic Studies in Indonesia?, (Makasar: PPs. UIN Alauddin, 2006), hlm. 242. hlm. 33 . tradisi atau ide dan realitas, tidak seharusnya dipandang sebagai keterlibatan saja, melainkan juga sikap netralis agar mampu melihat anomali-anomali atau penyimpangan-penyimpangan yang terjadi pada Islam dalam sejarah. Hal inilah yang menjadi faktor utama lesunya kajiankajian Islam dengan pendekatan yang lebih kaya, sintetik, dan objektif.

Kedua, masih banyaknya asumsi bahwa ilmu-ilmu keislaman identik dengan wahyu sehingga yang terjadi adalah apa yang disinyalir oleh Mohammed Arkoun dengan taqdîs al-afkâr ad-dîniyah (sakralisasi pemikiran keagamaan). Seperti yang dinyatakan Qadri Azizy, bahwa dalam tradisi Barat, ilmu beranjak dari suatu premis kesangsian, berbeda dengan ilmu-ilmu keislaman yang dalam level wahyu bersumber dari premis keyakinan. Di sini pula diskusi secara akademis sering macet, lantaran sudah dipatoki dengan wahyu tadi. Para pengkaji Islam sering terjebak oleh jerat orang Islam sendiri bahwa ilmu-ilmu keislaman seperti fiqh, kalam, tasawuf dan lainnya identik dengan wahyu. 
Padahal ilmu-ilmu tersebut mengandung probabilitas yang membuka adanya teori baru penumbang teori lama seperti qawl qâdim dan qawl jadîd-nya asy-Syâfi' $\hat{\imath}$, tidak seharusnya ditempatkan pada level wahyu, sehingga kini diskusinya hanya berlari di tempat. ${ }^{3}$ Akibat sakralisasi tersebut, ilmu-ilmu keislaman tadi menjadi tidak membumi, berubah menjadi untouchable, seolah tidak dapat tersentuh secara manusiawi dan oleh akal manusia.

Ketiga, kurang atau tidak jelasnya perangkat analisis keilmuan dalam ilmu-ilmu keislaman atau 'filsafat ilmu'nya (meminjam istilah Amin Abdullah). ${ }^{4} \quad$ Menurutnya, paradigma kefilsafatan mesti ada

\footnotetext{
${ }^{3}$ A. Qadri Azizy, Pengembangan Ilmu-Ilmu Keislaman, (Semarang: Aneka Ilmu, 2004), hlm. 12.

${ }^{4}$ Filsafat ilmu yang dimaksud Amin adalah struktur fundamental yang mendasari, melatarbelakangi, dan mendorong kegiatan praksis keilmuan. Lihat M. Amin Abdullah, "at-Takwil a'Ilmiy; ke Arah Perubahan Paradigma Penafsiran Kitab Suci” dalam Islamic Studies di Perguruan Tinggi; Pendekatan Integratif-Interkonektif, (Yogyakarta: Pustaka Pelajar, 2006), hlm. 192.
}

dalam sebuah ilmu, baik ilmu kealaman, ilmu sosial, ilmu humaniora, ilmu agama, studi agama, ilmu keislaman. Asumsi dasar seorang ilmuan, metode (proses dan prosedur) yang diikuti, kerangka teori, peran akal, tolak ukur validitas keilmuan, prinsip-prinsip dasar, hubungan subjek dan objek, merupakan beberapa elemen pokok yang terkait dengan struktur fundamental yang mesti ada dalam suatu bangunan keilmuan. Dalam hal ini, kerangka teori ternyata memiliki posisi determinan dalam wilayah kerja keilmuan, karena basis rasionalitasnya memang ada di situ, begitu pula dengan arah dan kedalaman analisis akademik, terlacak dari sebuah kerangka teori. Hal ini tentunya juga berlaku dalam ilmu-ilmu keislaman sebagai bangunan keilmuan yang telah dirumuskan oleh para ulama terdahulu sebagai respon terhadap tantangan kemanusiaan dan keagamaan yang dihadapi ketika itu.

Filsafat ilmu dalam ilmuilmu keislaman inilah yang menurut Amin kurang begitu dipahami oleh para dosen yang 
mengajarkan Dirâsah

Islâmiyyah, terlebih kajian tafsir gadis. Bagaimana kerangka teori yang digunakan dalam ilmu tafsir dan ilmu hadis misalnya, implikasi dan konsekuensinya pada wilayah praksis sosialkeagamaan. Apalagi sampai melakukan perbandingan antara berbagai sistem epistimologi pemikiran keislaman dan memberikan autokritik terhadap bangunan keilmuan yang biasa diajarkan untuk pengembangan keilmuan Islam lebih lanjut. Belum lagi menghubungkan asumsi dasar, kerangka teori, paradigma, metodologi serta epistimologi yang dimiliki suatu disiplin ilmu dengan disiplin ilmu lain untuk memperluas horizon dan cakrawala analisis keilmuan. Kajian-kajian seperti ini hampir belum banyak tersentuh dan didiskusikan dalam perkuliahan Studi Islam dan khususnya TH. Kekurangtertarikan para civitas akademika di PTAI terhadap filsafat ilmu dalam Islamic Studies ini disebabkan karena belum banyaknya penelitian dan buku yang disusun secara khusus untuk kajian tersebut. Selain itu, wilayah filsafat dan epistimologi keilmuan ilmu-ilmu keislaman memang terkesan sengaja dihindari pembahasannya karena sangat kompleks dan akan membingungkan umat. Namun hal ini justru berakibat fatal dengan termarginalnya Islamic Studies dari wilayah pergumulan keilmuan sosial dan budaya serta sulitnya upaya pengembangan wilayah dalam ilmu-ilmu agama tersebut.

\section{Aspek Material}

Secara material, problem yang berkembang dalam pengkajian Studi Islam di PTAI juga tidak jauh berbeda dengan persoalan metodologisnya. Pertama, problem material tersebut berpangkal pada materi itu sendiri. Pengajaran yang diberikan dalam Islamic Studies lebih banyak berkutat pada persoalan materi keislaman itu sendiri dan kurang menyentuh aspek metodologisnya. Sehingga yang terjadi adalah pengulangan dan pengulangan materi keislaman yang bersifat normatif doktriner yang pada gilirannya membuat macet kreatifitas pemikiran mahasiswa dan menyebabkan mereka mengalami kebingungan 
metodologis ketika ingin meneliti persoalan sosial keagamaan yang berkembang maupun mengkaji produk pemikiran ulama klasik, terutama yang berkenaan dengan kajian TH. Hal ini disebabkan karena para pengajar [dosen], seperti yang disinyalir Amin sebelumnya, memang tidak begitu tertarik untuk memahami 'filsafat ilmu' Islamic studies. Padahal setiap dosen yang mengajarkan 'ulûm ad-dîn, idealnya harus memberi porsi yang memadai untuk menjelaskan bagaimana kerangka filsafat keilmuan dan epistimologi ilmu-ilmu Islam yang akan dipelajari serta operasionalisasinya dalam wilayah penelitian dan pengembangannya dalam bidang masing-masing. Penyampaian hal tersebut tidak perlu menunggu diberikannya mata kuliah Metodologi Penelitian yang seringkali diberikan terlalu jauh melenceng dari vocal fokus yang diperlukan setiap disiplin keilmuan Islamic Studies.

Kedua, materi ilmu-ilmu umum diajarkan secara terpisah dengan ilmu-ilmu agama seperti yang kebanyakan terjadi di
PTAI. Ilmu-ilmu umum yang dimaksud seperti sosiologi, antropologi, administrasi, filsafat, dan lain-lain. Hampir semua mata kuliah yang diajarkan di fakultas yang ada di PT umum yang dianggap ekuivalen dengan fakultas dan jurusan yang ada di PTAI juga diajarkan. Namun karena pengajarannya yang dilakukan secara terpisah, akibatnya tidak bersentuhan dengan intisasi ilmu-ilmu keislaman yang menjadi core dalam pendidikan di PTAI. Persoalan menjadi semakin parah ketika ilmu-ilmu umum tersebut diajarkan hanya berkisar pada 'pengantar' atau berkutat pada sekian banyak definisi, jauh dari analisis. Seolah-oleh kalau sudah mengerti sekian banyak jumlah definisi itu dianggap cukup, meskipun tanpa analisis mengapa definisi itu berbeda, di mana letak perbedaannya, mengapa definisi-definisi itu berbeda, dan lain sebagainya. Padahal prasyarat untuk mengembangkan ilmu-ilmu keislaman adalah perlunya dialog yang intensif dengan disiplin keilmuan umum tadi.

\section{Aspek Strategi}


Selain problem metodologi dan materi, strategi dalam pembelajaran studi Islam juga mengalami beberapa masalah yang krusial. Pertama, pengajaran dan pengkajian kebanyakannya masih bersifat monologis. Monolog dalam arti tidak ada dialog yang intens antara pemikiran dosen dengan pemikiran para mahasiswanya terhadap perkembangan kajiankajian keislaman. Para mahasiswa, dengan latar belakang kehidupan dan pendidikan yang beragam, barangkali dapat mengemukan beberapa persoalan krusial terkait dengan kajian keislaman di masyarakatnya. Hal ini tentu menjadi masukan yan sangat berharga bagi dosen dalam mengembangkan MSI secara lebih komprehensif. Faktor utamanya mungkin sangat tergantung pada dosen itu sendiri sejauh mana dia bersikap apresiatif, terbuka, dan tidak apriori terhadap kritik dan pemikiran mahasiswanya. Terkadang dosen menganggap dirinya telah 'mapan' dalam keahlian yang dikuasainya, sehingga pemikirannya terkesan selalu diunggulkan dibandingkan mahasiswa, padahal jika dia mau mendengarkan aspirasi mereka tentunya akan ada hal baru yang didapat setelah terjadi dialog pemikiran antara keduanya. Kondisi ini semakin parah jika pengajaran dilakukan secara doktriner. Mahasiswa dituntut untuk selalu menerima apa pun masukan dari dosen sedang dosen tidak terlalu berkepentingan untuk menerima kritik dari mahasiswanya.

Kedua, pembelajaran studi Islam jarang menggunakan ilmu-ilmu bantu dari 'luar' sebagai dampak dari pengajaran ilmu-ilmu keislaman dan ilmuilmu umum secara parsial. Hal ini menurut Qadri Azizy menyebabkan minimnya karya orisinil yang sasaran kajiannya adalah Islam dengan menggunakan ilmu-ilmu bantu tadi. Faktor lainnya adalah karena kurangnya kemampuan dosen yang mengajarkan ilmuilmu bantu tersebut dan tuntutan PT yang ada serta kurang jelasnya tuntutan keilmuan PTAI. Namun yang lebih sulit lagi menurutnya adalah memperoleh hasil kajian Islam dengan menggunakan ilmu-ilmu 
bantu yang kemudian bermanfaat untuk menambah instrumen metodologis dalam memahami dan menafsirkan ajaran Islam atau setidaknya memahami ulang terhadap tafsir atau pemikiran terhadap Islam yang sudah ada. ${ }^{5}$

masih Ketiga, pola pengajaran pengulangan atau bahkan hafalan terhadap hasil pemikiran ulama klasik dan sangat kurang mengembangkan pemikiran dengan menggunakan metodologi yang sudah dihasilkan oleh ulama terdahulu, apalagi mengembangkan metodologi itu sendiri. Bahkan metodologi yang diajarkan sebagai ilmu harus dihafal, bukan sebagai alat untuk melakukan analisis, seperti ilmu ushul fiqh yang diajarkan di PTAI sebagai 'ilmu' atau bahkan 'dogma agama' yang dihafal bukan sebagai instrumen dalam memahami wahyu atau untuk berijtihad. Dalam istilah hermeneutika kontemporer yang dikutip oleh Amin Abdullah, corak pemahamannya masih bersifat 're-productive' dalam 45-46. arti lebih menonjolkan porsi pengulangan-pengulangan

khazanah intelektual Islam klasik yang dianggap sakral dan kurang bersifat 'productive' dalam arti lebih menonjolkan perlunya memproduksi makna baru yang sesuai dengan tingkat tantangan perubahan dan perkembangan konteks sosialekonomi, politik, dan budaya yang melingkupi kehidupan umat Islam kontemporer tanpa meninggalkan misi utama makna moral dan pandangan hidup alQur'an [sebagai sumber ajaran Islam]. ${ }^{6}$ Konkritnya, kebanyakan PTAI masih dalam taraf menerima, memahami, atau mungkin menghafal, pemikiran ulama tentang Islam, belum mampu mengembangkan pemikiran secara orisinil. $^{7}$

${ }^{6}$ Lihat M. Amin Abdullah, "Ide Pembaharuan dalam Filsafat Islam" dalam Islamic Studies, op.cit., hlm. 139.

${ }^{7}$ Dalam batas tertentu, perlu juga diakui bahwa ada pemikir muslim yang memang sudah menghasilkan pemikiran orisinal, namun belum banyak diketahui oleh dunia luar sebagai akibat dari kurang adanya penerjemahan global karya-karya ilmuan muslim dalam bahasa internasional, sehingga diperlukan 
Dialog Metodologis; Langkah Konstruktif Perlu Dipertimbangkan

Dari problematika studi Islam yang dikemukakan sebelumnya, baik yang menyangkut metodologi, materi maupun strategi, setidaknya pelajaran yang dapat diambil untuk menentukan langkah berikutnya dalam meng-handle persoalan-persoalan kajian Islam yang berkembang adalah perlunya penyegaran (refresh) dan perubahan paradigma (paradigm shift) dalam paradigma keilmuan Islamic Studies, terutama keilmuan fiqh. Selama ini, fiqh dan implikasinya dalam Islam dianggap kaku sehingga kurang responsif terhadap tantangan dan tuntutan perkembangan zaman, terlebih pada persoalan, HAM, hukum publik, pandangan tentang wanita dan non-muslim. Pintu ijtihad yang selama ini dianggap masih terbuka dan tidak pernah tertutup, tetap saja tidak berani didekati apalagi dimasuki oleh ilmu-ilmu keislaman. Ilmu-ilmu tersebut

adanya program penerjemahan global tersebut. selalu menahan diri untuk bersentuhan dan berdialog langsung dengan ilmu-ilmu baru yang muncul pada abad ke 1819, seperti antropologi, sosiologi, psikologi, filsafat, dan lainnya.

Oleh karena itu, agenda keilmuan mendesak yang harus dilakukan sekarang adalah dialog Timur-Barat ( $\underline{\text { Hiwâr al- }}$ Masyriq wa al-Maghrib), meminjam istilah model dialog Hassan Hanafî̀ dan Muhammad 'Âbid al-Jâbirî, ${ }^{8}$ dalam pengertian perlunya sintesis antara pendekatan normatif konvensional (seperti tafsir, hadis, dan ushûl al-fiqh) yang akar sejarah perkembangannya berasal dari Islam dan pendekatan-pendekatan ilmiah yang muncul di Barat, seperti sosiologi dan antropologi. Dengan pendekatan ganda tersebut, beberapa cacat metodologis dari masing-masing pendekatan normatif maupun historis akan dapat dieleminir sekecil mungkin. Richard C. Martin misalnya, seorang pakar

\footnotetext{
${ }^{8}$ Muhammad 'Abid al-Jâbirî, Hiwâr al-Masyriq wa al-Maghrib, dalam Faishal Jalûl (ed.), (Kairo: Madbouli, 1990).
} 
studi Islam secara tegas juga ingin membuka kemungkinan kontak dan pertemuan langsung antara tradisi berpikir keilmuan dalam Islamic Studies dan tradisi berpikir keilmuan dalam Religious Studies kontemporer yang telah memanfaatkan kerangka teori dan metodologi yang digunakan ilmu-ilmu sosial dan humaniora yang berkembang pada abad ke-18 dan ke-19.

Dialog dan pertemuan antara dua tradisi keilmuan tadi memang telah mulai dirintis oleh ilmuan-ilmuan muslim kontemporer. Dalam kajian tafsir al-Qur'an misalnya, pemahaman ayat dengan latar belakangnya (sabab an-nuzûl) yang secara konvensional hanya dibatasi pada riwayat (sima'), dapat ditopang dengan pemahaman kondisi sosiohistoris yang melingkupi penurunannya, yang oleh Fazlur Rahman dalam Islam and Modernity-nya disebut sebagai

\footnotetext{
${ }^{9}$ Lihat dalam tulisannya yang berjudul "Islam dan Religious Studies; an Introduction Essay" dalam Richard C. Martin (ed.), Approaches to Islam in Religious Studies, (Tucson: University of Arizona Press, 1985), hlm. 1-18.
}

occasions of revelation (syu'ûn an-nuzûl). ${ }^{10}$ Pendekatan sosiohistoris juga diterapkan dalam kajian hadis, semisal hadis tentang kewajiban disertai oleh mahram bagi wanita yang ingin bepergian (al-Bukhârî dan Muslim, al-Lu'lû' wa al-Marjân, no. 850) yang oleh sebagian feminis muslim dianggap sebagai hadis misoginis. Konteks sosio-historis dan antropologis harus diberikan ruang bersama-sama pendekatan normatif, sebagaimana dilakukan oleh Yûsuf alQardhâwî dalam Kaifa Nata'âmal ma' as-Sunnah anNabawiyyah. ${ }^{11}$ Ahmed an-Na'îm

${ }^{10}$ Fazlur Rahman, Islam and
Modernity, Transformation of an
Intellectual Tradition (Chicago: The
University of Chicago, 1982), h. 143.
Edisi dengan nomor halaman yang
sama juga bisa dilihat dalam Issa J.
Boullata (ed.), An Anthology of Islamic
Studies (Montreal: McGill Indonesia
IAIN Development Project, 1992).
Syu'ûn an-nuzûl (kondisi kesejarahan
turunnya ayat) berarti tidak memuat
sabab an-nuzûl secara spesifik,
melainkan juga kondisi kesejarahan
masyarakat Arab-Islam, sehingga
memerlukan disiplin lain, seperti
sejarah (terutama buku-buku sîrah dan
hadis sejarah).
11 Yûsuf al-Qardhâwî, Kayf
Nata'âmal ma' as-Sunnah an-


mempertanyakan teori naskh konvensional dengan tesisnya bahwa ayat-ayat Makkiyah yang lebih menekankan pada bobot nilai-nilai universal kemanusiaan tidak dapat dihapus begitu saja oleh ayat-ayat Madaniyah yang lebih bersifat partikular-spesifik. $^{12}$ Sementara Fatima Mernissi ${ }^{13}$ dan Amina Wadud-Muhsin ${ }^{14}$

mempertanyakan keabsahan hadis-hadis misoginis dengan menggunakan perangkat analisis gender. Pakar hukum Islam dan HAM lainnya seperti Mashood Baderin mengajukan tesis tentang adanya kompatibilitas antara HAM internasional dan hukum Islam dengan

Nabawiyyah; Ma'âlim wa Dhawâbith, (USA: al-Ma'had al-Âlamî li al-Fikr alIslâmî, 1990).

${ }^{12}$ Abdullahi Ahmed an-

Na'im, Towards an Islamic Reformation; Civil Liberties, Human Rights and International Law, (New York: Syracuse University Press, 1990).

${ }^{13}$ Fatima Mernissi, Beyond the Veil; Male-Female Dynamics in the Modern Muslim Society, (Bloomington: Indiana University Press, 1987).

${ }^{14}$ Amina Wadud-MUhsin, Qur'an and Woman, (Kuala Lumpur: Fajar Bakti, 1992). mempertemukan antara doktrin mashlahah dalam maqâshid asysyarî'ah (perspektif hukum Islam) dan doktrin margin of appreciation (perspektif HAM). ${ }^{15}$

Semua hal tersebut tidak lain hanyalah dimaksudkan untuk mengupayakan pengembangan dan pengayaan wacana analisis dan metodologi keilmuan serta penelitian terhadap ilmu-ilmu keislaman, atau dalam istilah filsafat ilmu kontemporer yang dipopulerkan Amin Abdullah dengan 'humanisasi ilmu-ilmu keislaman'-nya dan Qadri Azizy dengan 'sakralisasi ilmu-ilmu sekuler'-nya, khususnya dalam dimensi fiqh dan pranata sosial, lantaran fondasi formulasi keilmuan Islam abad pertengahan sangat jauh berbeda dengan kondisi sekarang, sehingga ia menjadi tidak relevan dan tidak memadai untuk menjawab kebutuhan masyarakat kontemporer. Setidaknya akan dapat menjadi

${ }^{15}$ Mashood A. Baderin, International Human Rights and Islamic Law, (Oxford: Oxford University Press, 2003), khususnya bab pendahuluan. 
empirik, solving problems, memberi pencerahan ke depan, serta sanggup menjadi proses dan salah satu alat untuk memenuhi janji agama sebagai rahmatan lil âlamîn.

Pengembangan Kajian Tafsir dan Hadis di Perguruan Tinggi Agama Islam

Sebagaimana yang

disebutkan sebelumnya, bahwa ketika studi Islam tersebut diarahkan pada dua disiplin ilmu keislaman yang sangat krusial, yaitu studi al-Qur'an (tafsir) dan studi hadis (kritik dan pemahaman), permasalahan kajian Islam akan menjadi semakin kompleks jika penguasaan metodologi yang kurang mapan, menyebabkan kajian TH mengalami stagnasi metodologis karena dasar-dasar epistimologi yang kurang jelas dan penjelalan materi yang berlebihan tanpa diimbangi dengan metodologinya.

Untuk itu, dalam rangka pengembangan dan pembaharuan dalam kajian $\mathrm{TH}$, ada beberapa hal yang harus disadari, bahwa dalam Islam, kemunculan ilmu-ilmu keislaman adalah untuk memahami wahyu yang kemudian dipraktekkan. Wahyu yang terwujud dalam al-Qur'an dan hadis menjadi referensi utama ilmu-ilmu tersebut. Sedangkan ilmu-ilmu keislaman tidak lain hanyalah produk ijtihad pada ilmuan muslim klasik, sama sekali tidak identik dengan wahyu. Keberadaan ilmu-ilmu agama tersebut bisa saja ditempatkan pada posisi yang tidak jauh, kalau tidak dikatakan sama, dengan ilmuilmu umum (sekuler) yang selama ini dikenal, setidaknya dalam rangka pembidikan epistimologi ini. Tentunya juga harus disadari akan adanya perbedaan esensial sebagai konsekuensi adanya sumber berupa wahyu Allah, meskipun dalam prakteknya akan memperoleh hasil paralel. Demikian pula harus disadari bahwa wahyu sebagai dasar tidak berarti kaku dan sempit, namun dapat pula berarti pembatas, ketika akan diperankan secara wajar, sesuai dengan ajaran wahyu itu sendiri. Dengan ini akan terjadi balance antara deduktif, berdasarkan dalil nas, dan induktif (empirik) 
berdasarkan akal dan dalil kauniyah.

Dalam hal ini, ada pembatasan yang sangat relevan yang dikemukakan Qadri Azizy untuk wilayah kajian TH. Menurutnya, para pengkaji muslim tidak perlu 'mengacakacak' al-Qur'an dan hadis sebagai wahyu. Nas-nas alQur'an dan hadis akan tetap seperti itu adanya (an-nushûs mutanâhiyah), tidak perlu diperbaharui. Selain itu, yang menjadi kajian adalah yang merupakan produk manusia, meskipun dianggap 'manusia suci', baik pemahaman dan penafsiran yang bersifat individual, kelompok, mazhab, pada era dan kondisi sosial ekonomi politik tertentu. Dengan demikian, semua disiplin ilmu-ilmu keislaman bisa menjadi luas jangkauannya, lantaran ilmu-ilmu tersebut adalah hasil ijtihad atau produk manusia. $^{16}$

Dengan berpijak pada demarkasi wilayah kajian Azizy tersebut, maka kajian-kajian tafsir misalnya, dapat 13-14. difokuskan pada kajian produk tafsir-tafsir klasik, perbedaan penafsiran, kadar subjektivitas mufasir dengan pengaruh lingkungan, pendidikan, dan lain sebagainya, sampai pada fenomenologi mufasir. Untuk kajian al-Qur'an, nampaknya harus dikritisi lebih lanjut kajian sebagian oreintalis, semisal kajian literatur John Wansbrough dalam Qur'anic Studies-nya $^{17}$ dan muridnya Andrew Rippin dalam Literary Analysis of Qur'an-nya. ${ }^{18}$ Fazlur Rahman sendiri mengkritik tajam dan menolak analisis Wansbrough dan Rippin. ${ }^{19}$

${ }^{17}$ John Wansbrough, Qur'anic Studies; Sources and Methods of Scriptual Interpretation, (Oxford: Oxford University Press, 1977), hlm. 43-52. Edisi dengan nomor halaman yang sama juga bisa dilihat dalam Issa J. Boullata (ed.), An Anthology of Islamic Studies (Montreal: McGill Indonesia IAIN Development Project, 1992).

${ }^{18}$ Lihat artikel Andrew Rippin, "Literary Analysis of Qur'an, Tafsir, and Sira; the Methodology of John Wansbrough" dalam Richard C. Martin (ed.), Approaches to Islam, op.cit., hlm. 151-163.

${ }^{19}$ Kritik Fazlur Rahman terhadap kajian literatur al-Qur'an yang dilakukan Wansbrough dan Rippin dalam artikelnya yang berjudul 
Terkait dengan metodologi tafsir, Amin Abdullah menawarkan konsep at-ta'wîl al'ilmî yang menjadikan teks atau lebih tepatnya pemahaman individu, kelompok, mazhab, aliran, organisasi, kultur terhadap teks sebagai 'objek' telaah keilmuan keislaman yang baru. At-ta'wîl al-'ilmî memanfaatkan pendekatan hermeneutis (al-qirâ'ah almuntijah) terhadap khazanah intelektual Islam, baik klasik, modern, maupun kontemporer. ${ }^{20}$

"Approaches to Islam in Religious Studies; Review Essay, dalam Richard C. Martin, Approaches to Islam, op.cit., hlm. 189-202.

${ }^{20}$ M. Amin Abdullah, "alTakwil al-'Ilmiy; ke Arah Perubahan Paradigma Penafsiran Kitab Suci" dalam Islamic Studies, op.cit., hlm. 185. Menurut Amin, selama ini istilah tafsîr lebih populer ketimbang ta'wîl. Padahal tafsir adalah cara memahami teks dengan menjadikan nya sebagai 'subjek' dan hanya menggunakan epistimologi bayânî (meminjam kategorisasi Âbid al-Jâbirî). Berbeda dengan takwil yang merupakan cara memahami teks dengan menjadikannya sebagai 'objek'. Kurang populernya istilah takwil karena adanya anggapan dari mainstream studi keislaman yang berjalan bahwa 'ulûm al-Qur'ân telah 'matang dan terbakar' (nadhija wa ihtaraqa).
At-ta'wîl al- 'ilmî sebagai model tafsir alternatif terhadap teks menggunakan jalur lingkar hermeneutis yang mendialogkan secara sungguh-sungguh antara paradigma epistimologi bayânî, paradigma epistimologi 'irfân̂, dan paradigma epistimologi burhânî dalam satu gerak putar yang saling mengontrol, mengkritik, memperbaiki dan menyempurnakan kekurangan pada masing-masing paradigma, khususnya jika masing-masing paradigma berdiri sendiri. Pesan keadilan dan kemanusiaan yang melekat dalam al-Qur'an yang sering disebut rahmatan lil âlamîn (universal) hanya dapat dipahami dengan baik jika para mufasir kontemporer memahami adanya tiga paradigma epistimologi pemikiran keislaman dan mampu mendialogkan secara kritisdinamis-proporsional, baik secara individu maupun kelompok sehingga eksklusifitas pemikiran dan kelembagaan sosial-keagamaan dapat dihindari dan kerjasama antar berbagai kelompok menjadi niscaya, tanpa harus mendahulukan prejudiceprejudice kultural, sosial, 
maupun keagamaan. Hanya dengan cara ini menurut Amin dapat tercapai apa yang disebutnya dengan 'transformasi sosial' dan 'humanisasi ilmuilmu keislaman' melalui penafsiran dan pemaknaan pesan-pesan kitab suci yang bersifat emansipatoris dapat teraktualisasikan baik secara teoritis maupun praktis.

Tawaran metodologis Amin Abdullah dalam diskursus tafsir ini nampaknya sebagai respon terhadap fenomena sakralisasi-desakralisasi teks alQur'an $^{21}$ yang merupakan implikasi dari ketidaksepakatan tentang kekal-tidaknya alQur'an. Menurutnya meskipun dalam ilmu-ilmu al-Qur'an, selalu disebut asbâb an-nuzûl yang jelas-jelas menerangkan adanya hubungan kausalitas yang positif antara pesan atau norma al-Qur'an dengan peristiwa sosial, ekonomi, politik yang mengitarinya,

${ }^{21}$ Sakralisasi teks menurut Amin lebih menggarisbawahi tidak adanya hubungan kausalitas antara ayat-ayat al-Qur'an dengan peristiwaperistiwa sosial-budaya yang melatarbelakanginya, sementara desakralisasi menekankan adanya hubungan kausalitas antara keduanya. namun uraian ini kurang begitu populer karena dianggap kurang religius dengan mengurangi penghargaan terhadap aspek kemahakuasaan Allah yang kekal abadi, tanpa harus didahului oleh peristiwa alam atau sosial kemasyarakatan. Konsep asbâb an-nuzûl sebenarnya lebih terkandung makna bahwa al-Qur'an sebagai dokumen kitab suci umat Islam yang bersifat historis dan 'terbuka', sehingga memungkinkan peluang munculnya pemaknaanpemaknaan baru. Namun karena konsep ini kurang mendapatkan tempat di hati umat Islam, alQur'an terkesan menjadi dokumen kitab suci yang terlalu 'metafisis' dan tertutup. Dimensi peristiwa keduniawian dan kekiniannya tereduksi seluruhnya menjadi semata-mata ketransendensian dan kesuciannya, sehingga sulit untuk mencari 'makna moral' di balik teks-teks tertulis secara historis. Penafsiran al-Qur'an yang bersifat leksiografis, kata perkata, kalimat perkalimat, ayat perayat, tanpa adanya pertimbangan konteks sosial, ekonomi, politik, budaya pada 
era sekarang adalah pola dan metode penafsiran yang cocok untuk sebuah kitab suci yang dianggap sebagai korpus 'tertutup', ahistoris. At-ta'wîl al'ilmî dalam hal ini merupakan alternatif model tafsir kontemporer yang diharapkan dapat mengatasi kesenjangan penafsiran tersebut.

Selain tafsir, kajian hadis pun nampaknya perlu mendapatkan pencerahan metodologi dan perubahan paradigma keilmuan. Hadis, yang selama ini dipahami sebagai ucapan, perbuatan, dan ketentuan Nabi saw. adalah bagian yang tidak terpisahkan, meminjam istilah Fazlur Rahman-, a living tradition (tradisi yang hidup atau asSunnah) ${ }^{22}$ di era kenabian selama 23 tahun berubah menjadi a literary tradition (tradisi tertulis) pada abad ke-2 dan ke-3 H. dalam kitab-kitab kumpulan hadis. Tanpa disadari umat Islam, telah terjadi perubahan yang mendasar dari tradisi 'lisan' yang hidup, longgar, dan fleksibel menjadi

\footnotetext{
${ }^{22}$ Fazlur Rahman, Islamic Methodology in History, (Pakistan: Islamic Research Institute, 1984).
}

tradisi 'tertulis', beku, kaku atau baku.

Dalam sejarah pembukuan hadis yang bersifat 'tertulis', sesungguhnya umat Islam saat itu 'dipaksa' oleh situasi yang mengitarinya, yaitu kelangkaan sahabat, tabi'in, dan tabi'it tabi'in yang mengetahui secara persis bagaimana cara praktik hidup, ibadah, dan perilaku Nabi saw. dan munculnya hadis-hadis palsu yang dibuat oleh generasi yang hidup setelah Nabi. Situasi seperti ini membuat para ilmuan muslim berupaya keras untuk menyeleksi hadis-hadis yang berasal dari Nabi dan yang bukan. Kemunculan ilmu-ilmu hadis, semisal Mushthala $\underline{h}$ al-

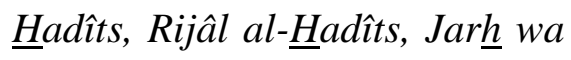
Ta'dîl, dan lain-lain merupakan bentuk intervensi keilmuan para ilmuan hadis melalui metodologi yang digunakan untuk menentukan mana yang berstatus Shahîh $\underline{h}$ Hasan, Dha' îf, dan begitu seterusnya. Dengan demikian, sebenarnya ada proses panjang yang bersifat historis dalam era tadwîn yang seringkali dilupakan umat Islam disebabkan karena maksud baik mereka untuk segera 
mengamalkan apa yang dibaca dan didengar sehingga kurang begitu peduli dengan proses dan asal usul munculnya sebuah hadis. Oleh karena itu, pengkajian ulang terhadap ilmuilmu hadis sangat mungkin dilakukan selama hal itu terkait dengan produk historis. Kategorisasi hadis (shahîh $\underline{h}$, hasan, dha't̂f) dengan segala derivasinya, ungkapan ashshahâbah kulluhum 'udûl, konsep jarh wa ta'dîl, kitabkitab syarh, merupakan lahan yang sangat mungkin untuk dikaji ulang.

$$
\text { Begitu pula dalam }
$$
melakukan pembacaan dan pemahaman ulang terhadap hadis secara komprehensif, perlu dilihat dahulu kedudukan hadis terhadap al-Qur'an. Posisi hadis dalam hal ini untuk menjelaskan dan menjabarkan kandungan alQur'an yang masih global. Ketika al-Qur'an memiliki muatan yang begitu kompleks, maka hadis pun harus menyesuaikannya. Menurut Muh. Zuhri, hadis setidaknya memiliki muatan-muatan berikut: pertama, informasi gaib dan akidah (bersifat dogmatik); kedua, norma-norma ritual dan sosial; ketiga, perilaku sebagai manusia biasa; dan keempat, gagasan menatap masa depan. Dengan kerangka ini akan dapat dipilah teks hadis yang harus dipahami apa adanya, dan teks hadis yang memberi keleluasaan dalam 'berijtihad'. Hadis-hadis yang bermuatan informasi gaib dan akidah yang bersifat dogmatik, nampaknya tidak dapat memberi 'banyak gerak' dalam berijtihad karena kebenarannya tidak dapat diukur dengan penalaran kreatif. Hadishadis tentang kiamat, malaikat, alam kubur, surga, neraka, tidak bisa dirasionalisasikan, harus dipercaya atau ditolak. Hal inilah yang nampaknya menjadi dasar pertimbangan mengapa dalam aspek gaib dan akidah diperlukan dalil yang mutawâtir, karena ia bersifat supra rasional dan universal, tidak terikat oleh waktu dan situasi. Begitu pula hadis-hadis tentang ritual ibadah seperti salat, puasa dan haji, meskipun dalam beberapa hal tidak seketat dogma akidah. Kendati peluang kritis terhadap ajaran ritual itu sempit, tetapi aktualisasi ritual yang melibatkan urusan duniawi, 
maka ada elemen-elemen hadis yang dapat dipertimbangkan. ${ }^{23}$

Berbeda dengan hadis yang memuat norma kemanusiaan. Situasi selalu mendorong munculnya sebuah norma. Perbedaan situasi akan mempengaruhi norma. Hadishadis yang bermuatan hukum sosial lebih memberi kelonggaran berkreasi karena ia berbicara tentang gejala sosial, yang ukuran kebenarannya mudah diamati berdasarkan kebutuhan sosial itu sendiri. Terlebih hadis-hadis yang berbicara dalam kapasitas Rasulullah sebagai manusia biasa, lebih mudah lagi dilihat konteksnya kemudian dirasionalisasikan. Kemudian sebagai pembawa agama, Rasulullah tentu memiliki obsesi agar pengikutnya menjadi masyarakat teladan dengan ciri utama rajin, setia, rasional, toleran, dan lainnya yang membawa kemajuan yang damai dan sejahtera. Hadis yang berupa gagasan dan cita-cita diperkirakan memberi

\footnotetext{
${ }^{23}$ Lihat Muh. Zuhri, Telaah Matan Hadis; sebuah Tawaran Metodologis, (Yogyakarta: LESFI, 2003), hlm. 50-51.
}

keleluasaan dalam aktualisasi. Setidaknya, ajaran moralnya tidak ditawar. ${ }^{24}$ Dengan demikian, hadis-hadis yang berkaitan dengan politik, sosial, ekonomi, dan budaya merupakan celah untuk dapat dilakukan kajian yang mendalam sekaligus perlunya pembaruan penafsiran, pemahaman dan pemaknaan yang tetap sesuai dengan ruh dan jiwa keislaman terhadap khazanah literatur hadis, mengingat situasi dan pranata sosial, ekonomi, budaya dan politik antara era pembukuan hadis dan era global sekarang sungguh sangat jauh berbeda.

\section{Kritik Pengembangan Studi Islam dalam Kajian Tafsir- Hadis}

Munculnya para pemikir muslim kontemporer semisal Fazlur Rahman, Abid al-Jabiri, Nasr Hamid Abu Zayd, Mohammed Arkoun, Fatima Mernissi, Riffat Hassan, dan tokoh-tokoh terkemuka lainnya, sungguh telah memberikan penyegaran dan sumbangan pemikiran orisinil (contribution of knowledge) terhadap 
pengembangan studi Islam, baik dalam tataran metodologi maupun materinya, dan berdampak besar terhadap kajian-kajian Tafsir dan Hadis yang selama ini melesu dan bahkan mengalami stagnasi metodologi.

Di satu sisi, pemikiranpemikiran para tokoh tersebut sudah selayaknya diapresiasi sebagai dinamika yang memperkaya khazanah intelektual Islam sebab bagaimanapun kemunculan pemikiran mereka merupakan respon positif terhadap perkembangan dan tantangan zaman global yang semakin kompleks. Berkat jasa mereka, studi Islam menjadi isu penting yang menjadi perhatian dunia, terlebih bagi kalangan oreintalis Barat dan pemerhati serta pengkaji Islam lainnya. Pengayaan metodologi, pengembangan wacana-wacana keilmuan Islam yang lebih kontekstual, menjadi karakteristik pemikiranpemikiran tersebut. Kini, kajiankajian tafsir maupun hadis sudah mulai bangun dari 'tidur panjangnya'. Pemaknaan, penafsiran dan pemahaman terhadap teks-teks al-Qur'an dan hadis yang semula terkesan kaku dan rigid menjadi lebih membumi dan responsif terhadap tuntutan zaman.

Namun di sisi lain, pemikiran-pemikiran tersebut tentunya harus dikritisi dan tidak mesti 'ditelan seratus persen' sebab bagaimanapun ia merupakan produk manusia yang tidak luput dari keterbatasan dan ketidaksempurnaan. Jika kita menelusuri sejarah perkembangan paradigmaparadigma dalam ilmu sosial, sebagaimana dijelaskan oleh George Ritzer, ${ }^{25}$ bahwa munculnya setiap paradigma adalah karena kritik terhadap keterbatasan paradigma yang telah ditawarkan dalam memahami realitas. Paradigma definisi sosial (social definition paradigm), misalnya, adalah kritik atas paradigma fakta sosial (social fact paradigm). Akhirnya, setiap paradigma memiliki keterbatasan, di samping keunggulannya, dalam membatasi realitas, karena

${ }^{25}$ George Ritzer, Sociology: A Multiple Paradigm Science, (Boston: Allyn and Bacon, Inc., 1980). 
realitas keagamaan adalah realitas yang kompleks. Kesimpulannya, Ritzer menyarankan paradigma integratif, yaitu paradigma yang menggabungkan paradigma fakta sosial, definisi sosial, dan perilaku sosial.

Sebenarnya, hal yang sama juga terjadi pada pendekatan-pendekatan dalam kajian Islam, khususnya kajian tafsir dan hadis. Harus dibangun anggapan bahwa tidak ada pendekatan tanpa keterbatasan, sebagaimana setiap pendekatan juga memiliki keunggulan. Jika dilakukan over-view pendekatan-pendekatan dalam mengkaji Islam, tentu akan sampai pada kesimpulan tidak ada pendekatan kajian Islam yang sempurna dan final karena realitas Islam adalah kompleks. Amin Abdullah sendiri pernah menyatakan bahwa 'finalitas' tidak memberikan kesempatan munculnya new possibilities yang barangkali lebih kondusif untuk menjawab persoalanpersoalan sosial-keagamaan kontemporer. Finalitas dan eksklusifitas sama sekali menepikan kenyataan bahwa keberagamaan Islam sungguh bukanlah peristiwa yang 'sekali jadi'. Keberagamaan adalah proses panjang (on going process of religiosity) menuju kematangan dan kedewasaan sikap beragama. ${ }^{26}$

Oleh karena itu, kritik terhadap pengembangan metodologi dalam studi Islam dan terkhusus kajian tafsir hadis menjadi suatu keniscayaan. Dalam hal ini, sebagian besar tawaran metodologis yang dikemukakan oleh para pemikir muslim kontemporer masih berada dalam tataran 'wacana' atau bersifat teoritis, belum banyak yang bersifat aplikatif. Di sinilah sebenarnya permasalahan dekonstruksi atau rekonstruksi pemahaman terhadap Islam dimulai. Kajian an-Na'im misalnya, dengan proposisi utamanya dalam reformasi hukum 'dari dalam' adalah bahwa untuk menyesuaikan prinsip-prinsip HAM internasional harus melalui proses terbalik ( $a$ reversed process) 'naskh' [penghapusan ayat al-Qur'an tertentu dengan ayat lainnya], di

\footnotetext{
${ }^{26}$ M. Amin Abdullah, "al-

Takwil al-'Ilmiy" dalam Islamic Studies, op.cit., hlm. 224.
} 
mana penerapan ayat-ayat Madaniyah akan diganti dengan ayat-ayat Makkiyah. Namun proposisi ini hanya dalam tataran teoritis dan sangat sulit dalam tataran praktisnya. Memang dalam melakukan 'dekonstruksi dan rekonstruksi syari'ah' merupakan tugas yang maha berat dan memerlukan proses yang panjang karena hal itu berarti harus meruntuhkan bangunan keilmuan hukum Islam yang sudah ada dan telah mapan selama berabad-abad dan menggantinya dengan bangunan keilmuan yang baru.

Tawaran Amin Abdullah dengan pendekatan ta'wîl 'ilmînya untuk merubah paradigma tafsir al-Qur'an juga masih dalam tataran wacana. Sebuah model tafsir al-Qur'an yang menerapkan secara interkonektif antara pendekatan bayânî (eksplanatif dengan berpusat pada nash/teks sebagai sumber kebenaran utama), burhân̂̂, (demonstratif dengan berpusat pada inteleksi dan penggunaan akal sebagai sumber kebenaran utama), dan 'irfânî (gnostik yang berpusat pada kebenaran intuitif) ini, tentu saja, tidaklah seluruhnya baru. Muhammad
'Âbid al-Jâbirî dalam tiga buku serial kritik nalar Arabnya (Takwîn al-'Aql al-'Arabî, Bunyat al-'Aql al-'Arabî, dan al'Aql as-Siyâsî̀ al-'Arabî) telah mengklafisikan tiga model epistemologi Arab-Islam itu. Berbeda dengan Amin, al-Jabirî sebenarnya tidak sama sekali memaksudkan tiga model epistemologi itu dalam konteks pembacaan kitab suci. Sebagai dosen dalam filsafat Islam, alJabirî mengklasifikannya sebagai keadaan intelektualitas Arab-Islam untuk tujuan dikritik demi sebuah nahdhah (kebangkitan) Arab yang diinginkannya. Namun, menggunakan bahan-bahan yang disusun oleh orang lain -meski semula untuk tujuan yang berbeda- untuk dibangun sebuah konstruksi metodologi "baru" adalah sesuatu wajar dan harus diapresiasi dalam konteks menatap masa depan Islam yang lebih baik. Hanya saja, permasalahannya adalah bagaimana aplikasi model tafsir interkonektif tersebut. Apakah ia dapat diterapkan untuk menafsirkan ayat al-Qur'an dan hadis dalam semua konteks, baik akidah, ibadah, maupun 
muamalah. Ini masih menjadi tanda tanya besar dan tugas maha berat bagi para pengkaji tafsir dan hadis.

$$
\text { Sebagaimana yang }
$$

dikemukakan Amin Abdullah, bahwa model kerja at-ta'wîl al'ilmî adalah dengan memanfaatkan gerak putar hermeneutis antar ketiga corak epistimologi keilmuan Islam (bayânî, 'irfânî, dan burhânî) susunan al-Jâbirî tersebut. Dengan begitu, kekeliruan, kekakuan, anomali, dan kesalahan yang ada pada setiap epistimologi dapat dikurangi dan diperbaiki, setelah memperoleh masukan dan kritik dari jenis epistimologi yang datang dari luar dirinya. ${ }^{27}$ Pendekatan ini nampaknya lebih cocok diterapkan pada ayat-ayat yang berkenaan dengan muamalah seperti hukum publik, normanorma kemanusiaan, pranata sosial, ekonomi, politik, dan budaya. Barangkali penafsiran dengan model interkonektif ini akan lebih konstruktif bahkan mungkin 'mengungguli' tafsir kontemporer yang dikembangkan Quraish Shihab.
Namun ketika pendekatan yang 'nyaris sempurna' tersebut diterapkan pada ayat-ayat tentang keyakinan dan ritual ibadah yang sudah pasti, maka pemaknaannya menjadi kabur karena sifat relatifitasnya, terlebih ketika pendekatan ini bercorak hubungan yang bersifat berputar-melingkar sirkular tidak menunjukkan adanya finalitas, eksklusifitas, dan hegemoni. Jika pengkaji tidak memiliki pijakan epistimologi keislaman yang mapan, mungkin akan membahayakan keyakinannya karena ada kecenderungan untuk penyamaan semua keyakinan agama, karena stuktur dasarnya yang sama, yaitu pengakuan akan adanya Tuhan.

Dalam kajian hadis, pemikiran-pemikiran baru yang dilontarkan para tokoh semisal Fazlur Rahman dan Muhammad al-Ghazâlî juga patut untuk dikritisi. Tidak seperti pemikiran M.M. Azami, pemikiran kedua tokoh ini cenderung mengabaikan signifikansi sanad dalam penentuan status hadis. Baik al-Ghazâlî maupun Rahman, menganggap tidak penting isnâd dalam hadis, 
karena kebenarannya tidak dapat dibuktikan secara empiris. Meskipun sanad telah meminimalkan upaya pemalsuan hadis, namun ia tidak dapat diterima begitu saja lantaran baru berkembang setelah wafatnya Nabi, yaitu menjelang abad pertama Hijrah, sehingga benarnya sanad tidak serta merta menjadikan hadis itu benar, karena mungkin kecacatan justru ada dalam matn hadis itu sendiri. Tesis ini barangkali di satu sisi benar, namun di sisi lain harus diperhatikan bahwa studi sanad merupakan hal yang tidak dapat dipisahkan dari hadis atau sunnah. Tanpa adanya sanad, tidak mungkin hadis-hadis tersebut sampai ke tangan umat sekarang, termasuk al-Ghazâlî dan Rahman yang mengkritisi hadis-hadis tersebut. Terlebih ketika dihadapkan pada temuan Azami, bahwa sanad sebenarnya sudah dikenal sejak zaman Nabi. $^{28}$

Adapun tesis bahwa kecacatan matn hadis bisa terjadi pada sanad yang sahih juga

${ }^{28}$ Sebagai bahan perbandingan lebih lanjut, lihat tulisan Ali Mustafa Yaqub, Kritik Hadis, (Jakarta: Pustaka Firdaus, 2000), hlm. 25-30. dapat dikritisi dengan persyaratan kesahihan sanad hadis. Dalam persyaratan tersebut sebenarnya sudah dapat dipertanyakan tesis tersebut. Dengan adanya syarat 'adâlah dan dâbith bagi setiap perawi misalnya, sangat kecil kemungkinan adanya cacat dalam redaksi hadis. ${ }^{29}$ Sebab sebagai perawi yang âdil dan dâbith, tidak mungkin akan menerima begitu saja hadis yang diperolehnya dari orang lain tanpa diseleksinya melalui pemahaman yang matang terlebih dahulu, apakah sesuai dengan kandungan al-Qur'an atau tidak. Begitu pula terhadap orang yang memberinya hadis, tentu dilihatnya dulu bagaimana orang tersebut, apakah layak untuk diterima hadisnya atau tidak. Al-Bukhârî misalnya, dari sekian ratus ribu hadis yang dihafalnya, hanya sekitar tujuh ribu hadis saja yang dimuat dalam kitab hadisnya. Ini menunjukkan betapa tinggi daya selektivitasnya terhadap hadis-

${ }^{29}$ Sebagai bahan komparasi, lihat juga Nûr ad-Dîn 'Ithr, Lamhât Mûjizah fî Manâhij al-Muhadditsîn al'Âmmah, (Damaskus: Dâr al-Farfûr, 1999), hlm. 9-10. 
hadis nabi. Karena itulah, tidak mengherankan jika kitab hadisnya diakui mayoritas ulama sebagai kitab hadis yang paling sahih setelah al-Qur'an, meskipun sebagai sebuah karya manusia, kitabnya tetap terbuka untuk ditelaah ulang dan dikritisi oleh umat belakangan.

\section{PENUTUP}

Dari uraian-uraian tadi, penulis dapat mencatat bahwa pengembangan dan pembaharuan studi Islam yang didengungkan oleh para pemikir muslim kontemporer kebanyakannya masih berkisar pada aspek muamalah seperti yang berkaitan dengan hukum publik, norma-norma kemanusiaan, pranata sosial, ekonomi, politik, dan budaya yang lebih menekankan aspek historisitas Islam meskipun tidak mengabaikan sisi normativitasnya. Belum banyak kajian-kajian keislaman baru yang menyentuh pada aspek akidah maupun ibadah karena memang aspek-aspek tersebut merupakan wilayah dogmatik dan sangat sensitif bagi umat Islam. Padahal para ilmuan klasik semisal asy-Syâfi' î dengan metodologi dan ijtihadnya berani 'menjamah' wilayah dogmatik dalam kajian fiqhiyah seperti ritual ibadah yang sampai kini tetap eksis sebagai mazhab Syafi'i. Nampaknya wilayah-wilayah memang tersebut tidak begitu dipermasalahkan, karena ia menjadi keunikan dan karakteristik Islam yang mesti dilestarikan meski dalam beberapa hal ada yang perlu untuk diperbaharui.

Kalau pun ada pemikiran kontemporer yang berani memasuki wilayah tersebut, permasalahan krusial yang muncul adalah apakah umat akan menerima tawaran keilmuan yang baru tersebut begitu saja?. Tentu akan sulit sekali dan banyak memerlukan perjuangan yang gigih serta pengorbanan yang besar. Nasr Hamid Abu Zayd misalnya, harus rela 'diusir' dan bahkan dikafirkan oleh pihak pengadilan di negaranya di Mesir karena kajian tafsirnya yang berkesimpulan bahwa al-Qur'an adalah produk budaya, identik dengan ajaran Muktazilah. Belum lagi kasus Amina Wadud yang pernah menjadi khatib dan 
imam Jum'at di sebuah gereja di New York, hingga kini masih menyisakan polemik karena tindakannya yang dianggap 'keluar' dari batas syari'ah karena ingin merubah paradigma keagamaan yang terlalu menyudutkan perempuan. Begitu pula kajian-kajian hadis baru Muhammad al-Ghazâlî yang banyak menimbulkan kontroversi yang menyebabkannya dituduh sebagai pengingkar sunnah karena ingin menekankan perlunya penelahaan yang intens terhadap redaksi-redaksi (matn) hadis yang selama ini dikategorikan sahih dari segi sanad-nya.

Memang, nampaknya umat Islam masih sangat sensitif terhadap persoalan-persoalan dogmatis dan ibadah fiqhiyah tersebut. Oleh karena itu, sudah saatnya umat Islam dapat bersikap bijak dan arif terhadap perkembangan pemikiran keislaman seiring lajunya perkembangan zaman dan tantangan global yang semakin kompleks. Perbedaan tradisi keilmuan dalam memahami Islam tidak perlu membuat umat untuk saling mengkafirkan, menyulut emosi individu dan kelompok, tetapi seharusnya mampu membina integritas dan mendewasakan cara berpikir umat Islam dalam menatap masa depan dan berinteraksi dengan zaman secara lebih baik.

\section{DAFTAR PUSTAKA}

Abdullah, M. Amin, Islamic Studies di Perguruan Tinggi; Pendekatan Integratif-Interkonektif, Yogyakarta: Pustaka Pelajar, 2006.

Adams, Charles J., "Islamic Religious Tradition" dalam Leonard Binder (ed.), The Study of The Middle East; Research and Scholarship in the Humanities and The Social Sciences, New York: John Wiley \& Sons, 1976.

Azizy, A. Qadri, Pengembangan Ilmu-Ilmu Keislaman, Semarang: Aneka Ilmu, 2004.

Baderin, Mashood A., International Human Rights and Islamic Law, Oxford: Oxford University Press, 2003.

Boullata, Issa J. (ed.), $A n$ Anthology of Islamic Studies, Montreal: 
McGill Indonesia IAIN Development Project, 1992.

'Ithr, Nûr ad-Dîn, Lamhât Mûjizah fî Manâhij alMuhadditsîn al-'Âmmah, Damaskus: Dâr al-Farfûr, 1999.

Al-Jâbirî, Muhammad 'Ābid, Hiwâr al-Masyriq wa alMaghrib, dalam Faishal Jalûl (ed.), Kairo: Madbouli, 1990.

Martin, Richard C. (ed.), Approaches to Islam in Religious Studies, Tucson: University of Arizona Press, 1985.

Mernissi, Fatima, Beyond the Veil; $\quad$ Male-Female Dynamics in the Modern Muslim Society, Bloomington: Indiana University Press, 1987.

Musahadi, "Islam sebagai Sasaran Studi" dalam Kamaruddin Amin et.al. (eds.), Quo Vadis Islamic Studies in Indonesia?, Makasar: PPs. UIN Alauddin, 2006.

An-Na'im, Abdullahi Ahmed, Towards an Islamic Reformation; Civil Liberties, Human Rights and International Law, New York: Syracuse University Press, 1990.
Al-Qardhâwî, Yûsuf, Kayf Nata'âmal ma' asSunnah an-Nabawiyyah; Ma'âlim wa Dhawâbith, USA: al-Ma'had alÂlamî li al-Fikr alIslâmî, 1990.

Rahman, Fazlur, “Approaches to Islam in Religious Studies; Review Essay, dalam Richard C. Martin (ed.), Approaches to Islam in Religious Studies, Tucson: University of Arizona Press, 1985.

--------, Islamic Methodology in History, Pakistan: Islamic Research Institute, 1984.

Rakhmat, Jalaluddin, "Metodologi Penelitian Agama" dalam Taufik Abdullah (ed.), Metodologi Penelitian Agama; Sebuah Pengantar, Yogyakarta: Tiara Wacana, 1990.

Rippin, Andrew, "Literary Analysis of Qur'an, Tafsir, and Sira; the Methodology of John Wansbrough" dalam Richard C. Martin (ed.), Approaches to Islam in Religious Studies, Tucson: University of Arizona Press, 1985. 
Wadud, Amina Muhsin, Qur'an and Woman, Kuala Lumpur: Fajar Bakti, 1992.

Wansbrough, John, Qur'anic Studies; Sources and Methods of Scriptual Interpretation, Oxford: Oxford University Press, 1977.

Yaqub, Ali Mustafa, Kritik Hadis, Jakarta: Pustaka Firdaus, 2000.

Zuhri, Muh., Telaah Matan Hadis; sebuah Tawaran Metodologis, Yogyakarta: LESFI, 2003. 